\title{
Upper Mantle Anisotropy in Brazil with SKS Splitting: Evidence for Asthenospheric Flow around the São Francisco craton
}

\author{
Marcelo Assumpção [IAG-USP], Maggy Heintz [RSES-ANU, Australia] \& Alain Vauchez [Univ. Montpellier, France]
}

Copyright 2006, SBGf - Sociedade Brasileira de Geofísica

Este texto foi preparado para a apresentação no II Simpósio de Geofísica da Sociedade Brasileira de Geofísica, Natal, 21-23 de setembro de 2006. Seu conteúdo foi revisado pela Comissão Tecno-cientifica do II SR-SBGf mas não necessariamente representa a opinião da SBGf ou de seus associados. E proibida a reprodução total ou parcial deste material para propósitos comerciais sem prévia autorização da SBG.

\begin{abstract}
Upper mantle anisotropy was studied with SKS phases in Central and SE Brazil. Although the fast polarization directions vary across the region, consistent orientations are observed over hundreds of kilometers. The average fast polarization directions is close to the absolute (HS3-NUVEL1A) plate motion but significant deviations are observed in some areas. The fast polarization directions show a fan-shaped pattern strongly suggesting asthenosperic flow around a thick and stiff keel in the southern part of the São Francisco craton, consistent with the high-velocity anomaly revealed by surface-wave tomography. The observed NW-SE directions in the southern part of the Brasilia belt may also indicate asthenospheric flow channeled between the São Francisco craton and a cratonic block beneath the Paraná basin.
\end{abstract}

\section{Introduction}

The study of seismic anisotropy yields information on the strain-induced fabric within the Earth and allows an understanding of the deformation or the structure of the mantle. A shear wave propagating through an anisotropic medium is split into a fast and a slow shear waves polarized in mutually perpendicular directions. Seismological and petrophysical studies (e.g., Savage, 1999) suggest that the main source of anisotropy that causes splitting of SKS waves is located within the first $400 \mathrm{~km}$ of the upper mantle and is related to the crystal preferred orientation of olivine (CPO), the most abundant and deformable mineral in the upper mantle.

The development of olivine CPO in the upper mantle may result from past or present deformation. Past tectonic deformation processes imprint the lithospheric upper mantle with a crystallographic fabric which remains stable after thermal relaxation, referred to as "frozen anisotropy" (e.g., Vauchez and Nicolas, 1991; Savage, 1999). Olivine CPO also develops with present deformation and flow of the asthenospheric mantle related to plate motion, which is the main cause of upper mantle anisotropy beneath oceanic basins (Hess, 1964; Tommasi, 1998; Wolfe and Silver, 1998).

Savage (1999) reviewed the debate regarding the dominant cause of the anisotropy in stable continental areas, lithospheric (frozen) versus asthenospheric (plate motion), and recognized that no single hypothesis can explain all observations, and both lithospheric and asthenospheric anisotropy can contribute to the shear-wave splitting beneath continents, with asthenospheric flow perhaps being channelled along topography at the base of the lithosphere (e.g., Bormann et al., 1996; Barruol et al., 1997). Few seismic anisotropy measurements have been made in South America, east of the Andes, and lithospheric (James \& Assumpção, 1996) as well as asthenospheric sources (Helffrich et al.,2002) have been invoked. Analysis of SKS splitting in the Riberia belt by Heintz et al.(2003) suggests that both lithospheric and asthenospheric fabrics may contribute.

Seismic anisotropy below a seismic station can be inferred with core-refracted $S$ waves such as SKS. These waves arrive at the station at nearly vertical incidence and should be polarized along the radial direction. Quite often, however, SKS waves exhibit energy on the transverse component, which is best explained as the result of shear-wave splitting due to propagation within an anisotropic medium.

Two parameters are measured at the station: 1) $F P D$, the fast polarization direction of the S-wave, regarded as a proxy for the orientation of the [100] axis of olivine in the upper mantle, and 2) $d t$, the delay between the arrival time of the fast and slow split waves. $d t$ is proportional to the thickness and the intrinsic anisotropy of the anisotropic layer. The average delay time measured in continental areas is $1 \mathrm{~s}$ (Silver, 1996), although delays $>2 \mathrm{~s}$ have been measured above large strike-slip fault systems (e.g., station IGAB on the Ribeira transcurrent fault system, Heintz et al., 2003). This study presents data collected at 48 stations in SE and Central Brazil.

\section{Data processing}

S- wave splitting was measured using Silver and Chan's (1991) algorithm: the FPD and the lag time between fast and slow components $(d t)$ are determined through a grid search by correcting the observed components from the anisotropy effect to minimize the energy on the transverse component (Fig. 1). This method assumes anisotropy to in a single layer.

\section{Results}

Fig. 1 shows the anisotropy measurements for station canb in the central part of the Paraná Basin. Fig. 2 shows all measurements carried out at three stations (BDFB, corb, and canb) with respect to the event backazimuth. If the initial polarization of the incoming wave 
is parallel or orthogonal to the fast anisotropic direction, or if there is no anisotropy beneath the station, this will result in a lack of energy on the transverse component. Those measurements ('nulls') arise when the event back-azimuth is parallel to the fast or slow direction.

slalion CNB, evenl 1999,316 dist=99 Bkz=50

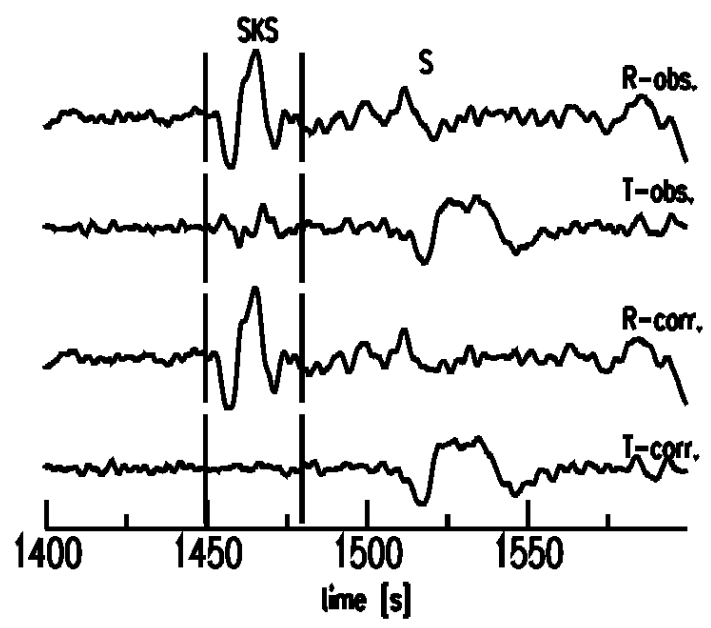

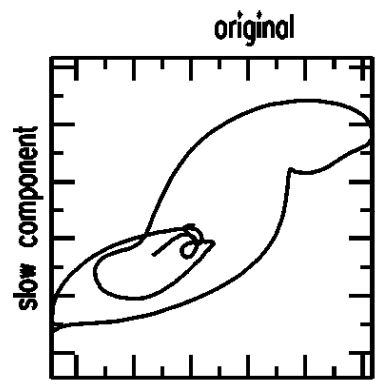

fast component delay correcled

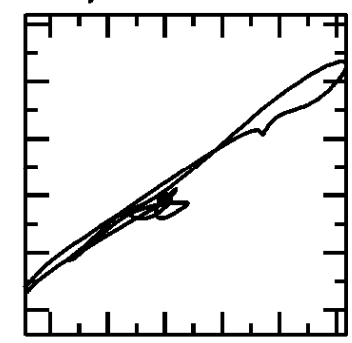

fast component

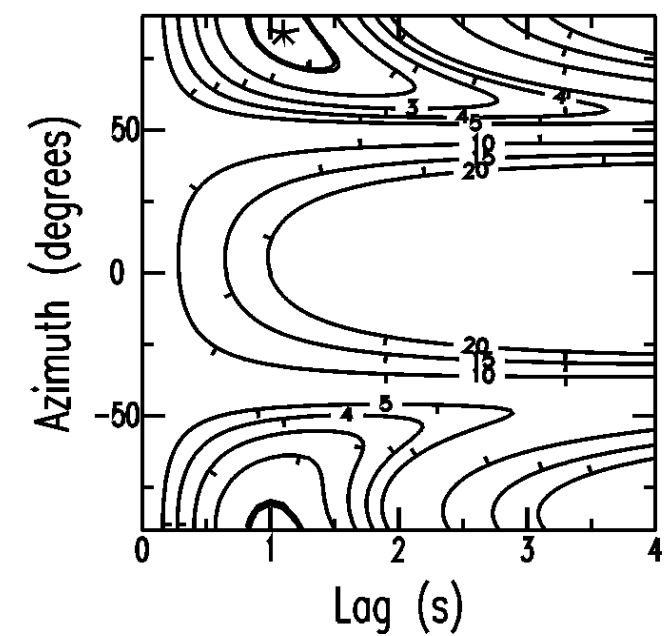

Fig. 1. SKS splitting for station canb in the Paraná Basin. Top: first two traces are the original radial and transverse records showing a large signal on the transverse component; bottom two traces are the anisotropy corrected signals; the vertical lines are the analysis window. Middle diagrams: original and corrected particle motions. Bottom diagram: energy contour of the transverse energy as a function of the $d t$ ("lag") and the fast polarization Azimuth (FPD); star is the best solution. Note that the correction calculated for the SKS phase also reduces the transverse component of the SKKS phase.

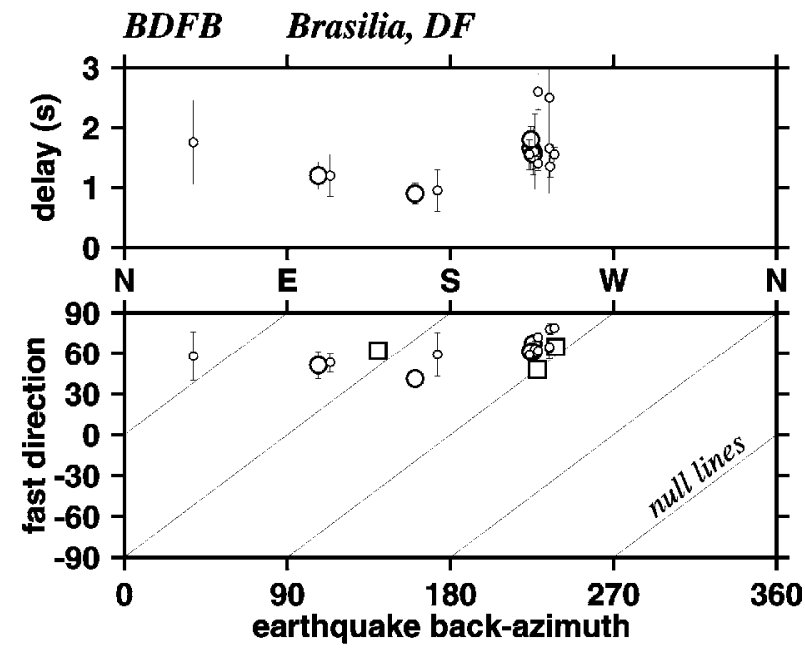

○ good data $\square$ null result

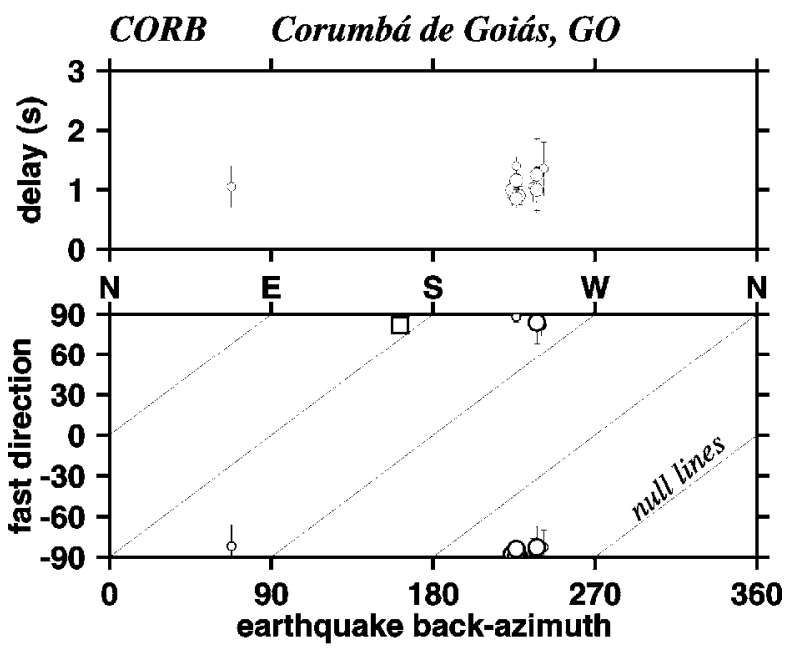

good data $\quad$ null result

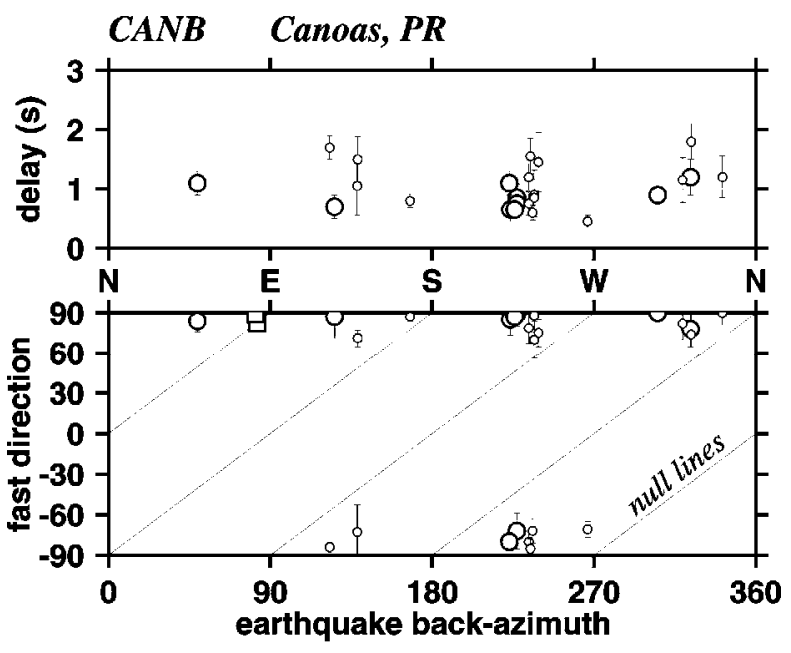

○ good data $\square$ null result

Fig. 2. Time delay $d t$ (top) and FPD (bottom) with respect to event backazimuth. Large and small circles are good and fair measurements. The inclined lines in each bottom diagram are locii of backazimuth parallel to the fast or slow directions, near which one should expect null results (square). (a) station BDFB, (b) station corb, (c) station canb 
Fig. 2 also shows that the fast polarization direction measured at the station does not vary with the back-azimuth of the event. The average direction for a station was then taken as the mean direction of all measurements. The average time delay at a station was computed as the mean of all individual measurements.

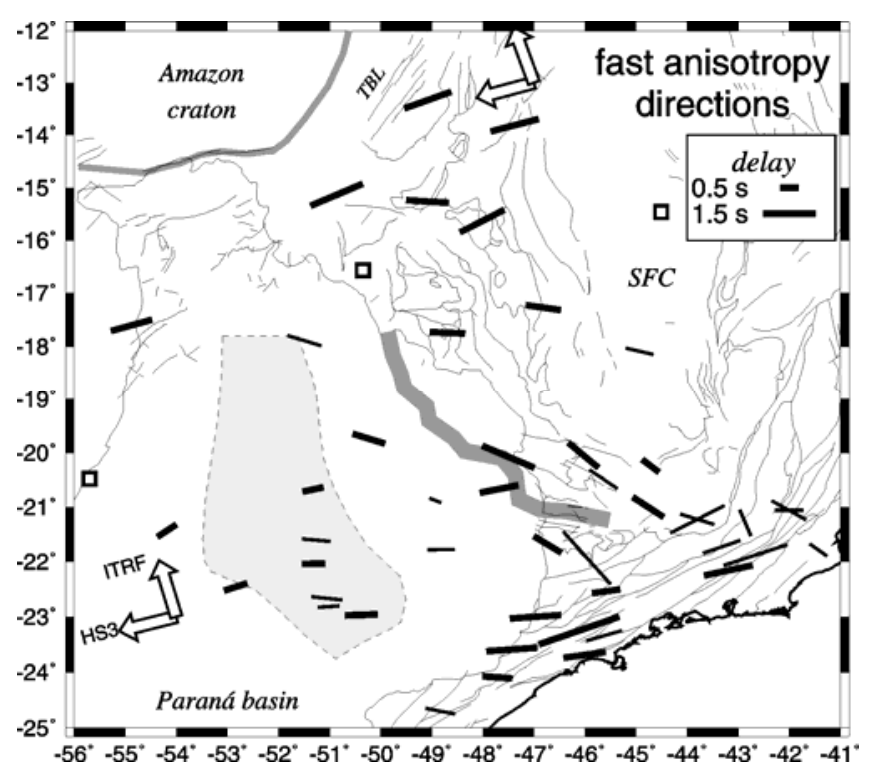

Fig. 3. Fast polarization directions. Thick and thin bars are good and fair average direction for each station. Squares indicate stations with no reliable fast direction. Thin lines show main geological faults (Schobbenhaus and Billizzia, 2000). The two arrows indicate the absolute plate motion according to the fixed hot-spot model HS3-NUVEL1A (Gripp and Gordon, 2002) and the GPS/ITRF model (Prawirodirdjo and Bock, 2004).

Fig. 3 compares the fast S-wave polarization directions (this study and data from James and Assumpção (1996) and Heintz et al. (2003)) with the structural trend in Central and SE Brazil. Although the fast polarization directions are not uniform in the whole study area, consistent patterns within ranges up to 500 $\mathrm{km}$ can be observed. In the Tocantins Province, FPD is close to $\mathrm{N} 60^{\circ} \mathrm{E}$ from station $p p 1 b$ to $\mathrm{cv} 1 \mathrm{~b}$. Within the Paraná basin, above the cratonic nucleus, small splitting delays and EW fast S-wave polarizations were retrieved. In the southern Brasilia belt and northeastern Paraná basin, FPD trends NW-SE roughly parallel to the Goiânia suture. In the central part of the Ribeira belt, FPD is ENE oriented. Interestingly, the anisotropy of electrical resistivity determined by long-period magnetotelluric surveys (Padilha et al., 2006) is generally consistent with the seismic anisotropy: observed directions of maximum conductivity are ENE across the Ribeira belt, and WNW in the southern Brasília belt, SW of the São Francisco craton.

Fig. 4 compares all measured $F P D$ with the absolute plate motion (APM) given by the HS3NUVEL1A model (Gripp and Gordon, 2002). For this model, SE Brazil moves towards WSW (Fig. 3). Despite the large scatter in Fig. 4, the peak of the distribution is very close to that predicted by HS3-NUVEL1A model.
Given the wide distribution of our stations across different tectonic provinces, this coincidence seems to indicate that an asthenospheric contribution to the observed anisotropy is very likely and that the absolute motion of the South American plate is probably close to that predicted by the HS3-NUVEL1A model.

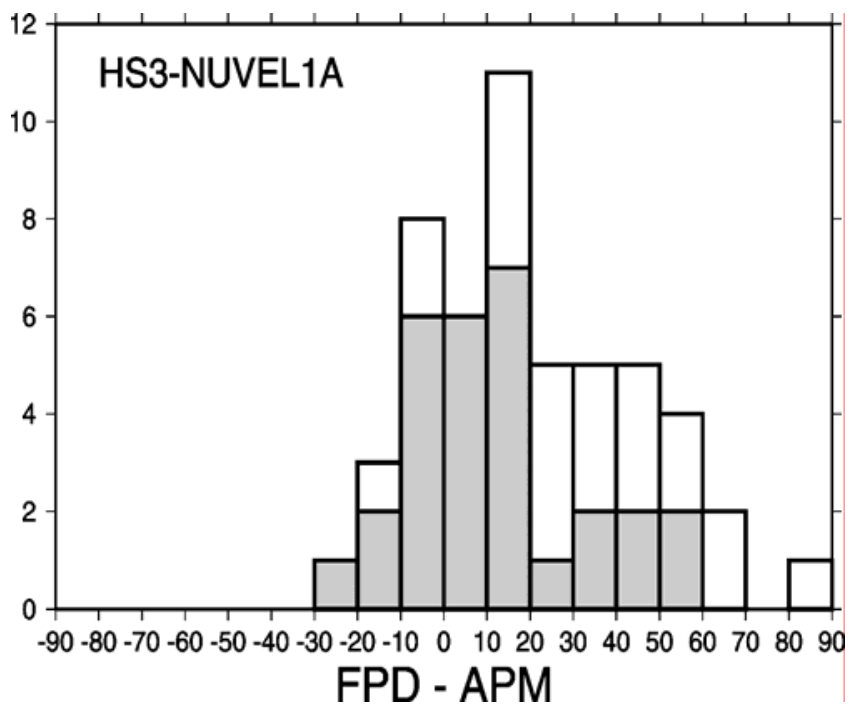

Fig. 4. Comparison of the fast polarization direction (FPD) with the absolute plate direction (APM, HS3NUVEL1A). Gray and open bars indicate good and fair data, respectively.

\section{Discussion}

Ribeira belt

In the Ribeira belt, the fast shear waves display polarization directions close to the WSW-ENE trend of the fold belt, especially in its central part, where transcurrent shear zones predominate. Heintz et al.(2003) proposed that both frozen fabric in the lithosphere and APM related fabric in the asthenosphere contribute to the observed SKS splitting.

\section{Paraná basin}

In the Paraná basin, two groups of fast polarization directions are present. In the NE part, the fast polarization direction tends to be NW-SE oriented, parallel to the general trend in the metamorphic core of the Brasilia belt and consistent with its presence beneath the edge of the sedimentary basin. In the central part of the basin, where a possible cratonic nucleus has been proposed (Cordani et al., 1984; Zalan et al. 1990; Mantovani et al., 2005) the anisotropy is small (delays less than $1.0 \mathrm{sec}$ ) but consistently EW oriented. This may indicate a different origin for the deformation induced anisotropy beneath the central part of the basin.

\section{Tocantins Province}

In the southern part of the Brasilia fold belt, SW of the São Francisco craton, the fast split waves are polarized NW-SE, parallel to the Goiannia flexure (thick gray line in Fig. 3) and the general structural trend of the belt. This area is also characterized by prominent aero-magnetic anomalies oriented NW-SE. This orientation is consistent with a collision between 
the Paranapanema cratonic block beneath the Paraná basin and the São Francisco craton, as previously shown by James and Assumpção (1996). In the northern Tocantins province the fast polarization directions trend WSW-ENE, significantly oblique with respect to the main geological units and the Transbrasiliano Lineament (TBL, Fig. 3). Therefore, the observed anisotropy is probably not directly related to the TBL, but rather to an asthenospheric source.

\section{Fan-shaped pattern and asthenospheric flow}

The E-W fast S-wave polarizations in the central part of the Brasília belt and São Francisco Craton is intermediate between ENE polarizations further North in the Tocantins province and the NW-SE polarizations observed in the southern part of the Brasilia belt. Similarly, the EW directions observed in the central core of the Paraná basin are also intermediate between ENE directions observed at two stations just SW of the central core and the NW-SE orientations along the Goiânia flexure. This fan-shaped pattern of $F P D$ suggests an asthenospheric fabric caused by flow around the São Francisco Craton.

Fig. 5 shows the S-wave velocity anomalies obtained from a continental scale Rayleigh-wave tomography by Feng et al.(2006) using a joint inversion of waveforms and group velocities. The seismic velocity model at $150 \mathrm{~km}$ depth (Fig. 5a) suggests that the São Francisco Craton lithospheric thickness is larger in the southern part than in the central and northern parts. The fast polarization directions tend to wrap around the cratonic root strongly suggesting asthenospheric flow around the craton's keel. The anomalies around $250 \mathrm{~km}$ depth (Fig. 5b) show a NW-SE low-velocity channel between the craton and the high velocity lithospheric block beneath the Paraná basin. The parallelism between FPD and this low-velocity channel supports an asthenospheric flow controlled by topography of the lithosphere/asthenosphere boundary.

Our preferred model to explain the observed patterns of SKS splitting consists of a main contribution from APM-related asthenospheric flow deflected by the São Francisco keel. Additional lithospheric anisotropy is also evidenced in two areas: the southern Brasilia belt and in the central part of the coastal Ribeira belt. In these two areas the large splitting delays and the correlation between FPD and geological trends indicate lithospheric frozen anisotropy from the Brasiliano orogen with lineations roughly parallel to those caused by the present APM-related asthenospheric flow.

\section{Conclusions}

The distribution of all observed fast polarization directions, over different geological provinces, has a peak near the HS3-NUVEL1A absolute plate motion. A clear fan shaped pattern is observed around high upper mantle S-wave velocities (in the southern São Francisco craton and in a lithospheric block beneath the Paraná basin). These observations strongly suggest that the observed anisotropies have an important contribution from APM-related asthenospheric flow modified by topography of the lithosphere/asthenosphere boundary. A constructive interference of asthenospheric and lithospheric anisotropies is proposed for the southern Brasilia and the Ribeira belts where the degree of splitting is larger and the FPD is parallel to the structural grain.

\section{Acknowledgments}

This study was supported by FAPESP grants 96/01566-0, 97/03640-6, 01/06066-6; CNPq 30.0227/79-5, 52.0078/00-4; and CNRS. We thank José Roberto Barbosa, Andrea Tommasi and Guilhem Barruol for help during field work.

\section{References}

Barruol, G. \& D. Mainprice, 1993. A quantitative evaluation of crustal rocks to the shear-wave splitting of teleseismic SKS waves. Phys. Earth Planet. Int., 78(34), 281-300.

Barruol, G., Silver, P.G. and Vauchez, A., 1997. Seismic anisotropy in the eastern United States: Deep structure of a complex continental plate. J. Geophys. Res., 102(B4): 8329-8348.

Ben Ismaïl, W. and Mainprice, D., 1998. An olivine fabric database: an overview of upper mantle fabrics and seismic anisotropy. Tectonophysics, 296: 145-158.

Bormann, P., G. Grunthal, R. Kind and H. Montag, 1996. Upper mantle anisotropy beneath central Europe from SKS wave splitting: effects of absolute plate motion and lithosphere-asthenosphere boundary topography. J. Geodynamics, 22, 11-32.

Cordani, U.G., B.B. Brito Neves, R.A. Fuck, R. Porto, A.T. Filho, \& F.M.B. Cunha, 1984. Estudo preliminar de integração do pre-Cambriano com os eventos tectônicos das bacias sedimentares brasileiras. Rev. Ciência Técnica, Petrobrás.

Feng, M., S. Van der Lee and M. Assumpção, 2006. Upper mantle structure of South America from joint inversion of waveforms and fundamental-mode group velocities of Rayleigh waves. J.Geophys.Res., submitted.

Gripp, A.E., and R.G., Gordon, 2002. Young tracks of hotspots and current plate velocities. Geophys. J. Int., 150, 321-361.

Heintz, M., A. Vauchez, M. Assumpção, G. Barruol and M. Egydio-Silva, 2003. Shear wave splitting in SE Brazil: an effect of active or fossil upper mantle flow, or both, Earth Planet. Sci. Lett. 211, 79-95.

Helffrich, G., D.A. Wiens, E. Vera, S. Barrientos, P. Shore, R. Stacey, and R. Adaros, 2002. A teleseismic shear-wave splitting study to investigate mantle flow around South America and implications for plate-driving forces. Geophys. J. Int., 149, F1-F7.

Hess, H.H., 1964. Seismic anisotropy of the uppermost mantle under oceans. Nature, 203: 629-631.

James, D.E. \& M. Assumpção, 1996. Tectonic implications of S-wave anisotropy beneath SE Brazil. Geophys.J.Int., 126, 1-10.

Mainprice, D. \& P.G. Silver, 1993. Interpretation of SKS waves using samples form the subcontinental lithosphere. Phys. Earth Planet. Int., 78, 257-280. 
Mantovani, M.S.M., M.C.L. Quintas, W. Shukowsky and B.B. Brito Neves, 2005. Delimitation of the Paranapanema Proterozoic block: a geophysical contribution. Episodes, 28(1), 18-22

Nicolas, A. and Christensen, N.I., 1987. Formation of anisotropy in upper mantle peridotites - A review. In: K. Fuchs and C. Froidevaux (Editors), Composition, structure and dynamics of the lithosphereasthenosphere system. Am. Geophys. Un., Washington, D.C., pp. 111-123.

Padilha, A.L., I. Vitorello, M.B. Padua, M.S. Bologna, 2006. Lithospheric and sublithospheric anisotropy beneath central-southeastern Brazil constrained by long period magnetotelluric data. Phys. Earth Planet. Int., submitted.

Prawirodirdjo, L. and Y. Bock, 2004. Instantaneous global plate motion model from 12 years of continuous GPS observations. J.Geophys.Res., 109 (B08405), doi:1029/2003JB002944.

Savage, M.K., 1999. Seismic anisotropy and mantle deformation: what have we learned from shear wave splitting? Rev. Geophys., 37 (1), 65-106.

Silver, P.G., 1996. Seismic anisotropy beneath the continents: probing the depths of geology. Annu. Rev. Earth Planet. Sci., 24, 385-432.

Silver, P.G. \& W.W. Chan, 1991. Shear wave splitting and subcontinental mantle deformation. J. Geophys. Res., 96(10), 16429-16454.
Schobbenhaus, C, and A. Bellizzia (coords.), 2000. Geological Map of South America, 1:5,000,000. CGMW-DNPM-CPRM-UNESCO, Brasília, Brazil.

Tommasi, A., 1998. Forward modeling of the development of seismic anisotropy in the upper mantle. Earth and Planetary Science Letters, 160: 1-13.

Vauchez, A., A. Tommasi, G. Barruol \& J. Maumus, 2000. Upper mantle deformation and seismic anisotropy in continental rifts. Phys. Chem.Earth $(A), 25$, 111-117.

Vinnik, L.P., L.I. Makeyeva, A. Milev \& A. Y. Usenko, 1992. Global patterns of azimuthal anisotropy and deformation in the continental mantle. Geophys. J. Int., $111,433-447$

Wolfe, C. and Silver, P.G., 1998. Seismic anisotropy of oceanic upper mantle: shear wave splitting methologies and observations. J. Geophys. Res., 103: 749-771.

Zalan, P., S. Wolf, J. Conceiçãoo, A. Marques, M. Astolfi, I. Vieira, V. Appi, \& O. Zanotto, 1990. Bacia do Paraná, in "Origem e Evolução de Bacias

Sedimentares", Eds. G. Raja Gabaglia, and E. Milani, Petrobrás, Brazil, 135-168. 

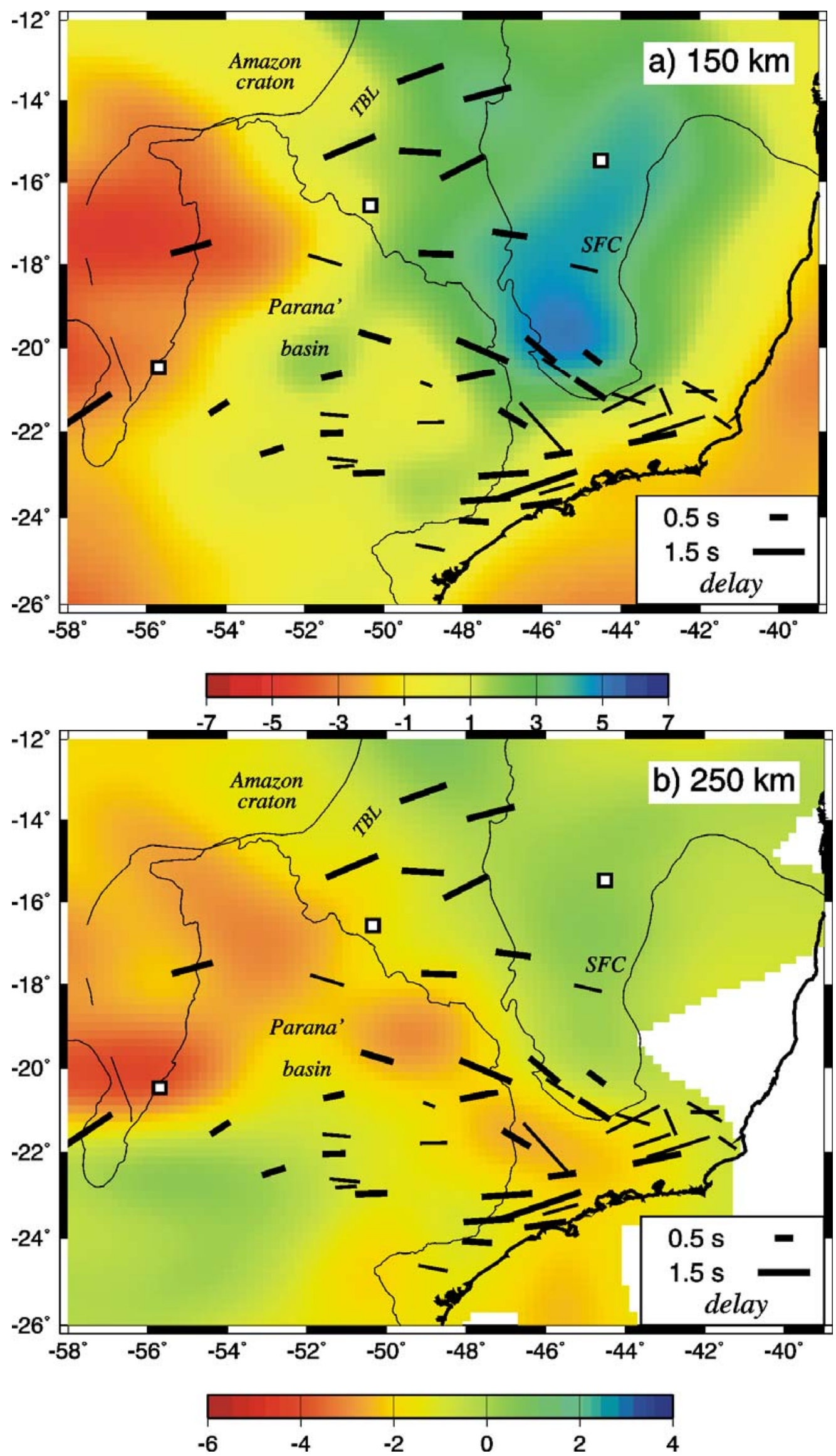

II Simpósio Brasileiro da SBGf, Natal 21-23 de setembro de 2006
Fig. 5.

Fast polarization directions (black bars) from shearwave splitting and S-wave velocity anomalies from surface-wave tomography of Feng et al.(2006). Colour scale is \% anomaly with respect to the IASP91 model.

(a) anomalies at $150 \mathrm{~km}$ depth. Note the thicker lithospheric root of the southern part of the São Francisco craton. The fast polarization directions display a fan-shaped pattern suggesting a deflection around the craton keel.

(b) velocity anomalies at $250 \mathrm{~km}$ depth. Note the low-velocity "channel" between the São Francisco craton and a high-velocity block beneath the Paraná basin suggesting flowinduced anisotropy related to topography of the lithosphere/ asthenosphere boundary. 